\title{
Penguins of the Magellan region*
}

\author{
M. BINGHAM and E. MEJIAS \\ Environmental Research Unit, PO Box 434, Stanley, Falkland Islands. E-mail: mbingham@ horizon.co.fk or \\ research@falklands.net
}

\begin{abstract}
SUMMARY: The Magellan region, including the Falkland Islands, is one of the world's most important areas for seabirds, and especially penguins. World-wide there are 17 species of penguin; 7 of these regularly breed around the coastal waters of South America, and 5 within the Magellan region. These are the King Penguin (Aptenodytes patagonicus), Gentoo Penguin (Pygoscelis papua), Rockhopper Penguin (Eudyptes c. chrysocome), Macaroni Penguin (Eudyptes chrysolophus) and Magellanic Penguin (Spheniscus magellanicus). During the last five years, a review of the breeding populations of penguins within the Magellan region was conducted. This work included population censuses of all the surface breeding species throughout the Falkland Islands and southern South America. The results of this work are presented, along with other cited information, to provide a summary of the current knowledge of penguin populations within the Magellan region.
\end{abstract}

Key words: Penguin, Magellan, Falkland, Chile, Argentina.

RESUMEN: Los Pingüinos DE LA REgión DE MAGELLANES. - La región de Magallanes, incluyendo las Islas Falkland, es un área muy importante para las aves marinas del mundo. Hay 17 especies de pingüinos; 7 crían en América del Sur y 5 crían en la región de Magallanes. Se trata de los Pingüino Rey (Aptenodytes patagonicus), Pingüino Papúa (Pygoscelis papua), Pingüino de Penacho Amarillo (Eudyptes c. chrysocome), Pingüino Macaroni (Eudyptes chrysolophus) y Pingüino de Magallanes (Spheniscus magellanicus). Durante los últimos 5 años investigamos las poblaciones de los pingüinos en la región de Magallanes. Esta investigación incluyó registros de todas las especies que crían sobre la tierra en las Islas Falkland y en el extremo meridional de América del Sur. Presentamos nuestros resultados con información de otra literatura citada para proporcionar un resumen del conocimiento sobre las poblaciones de los pingüinos en la región de Magallanes.

Palabras clave: Pingüino, región de Magallanes, Islas Falkland, Chile, Argentina.

\section{INTRODUCTION}

During 1995/96, a population census of all penguin species (except the Magellanic Penguin) was conducted around the Falkland Islands (Bingham, 1998b). Every breeding colony was visited, and population totals for each species obtained. Comparing these data with previous studies revealed that the Southern Rockhopper population had crashed to a fraction of its former size (Bennett, 1933; Bing-

\footnotetext{
*Accepted January 25, 1999
}

ham 1994c, 1995a, 1998b). With no obvious reason for this dramatic decline, apart from speculation about commercial fishing, it became a priority to census the remainder of the world population located in South America, to determine how wide-spread the decline had been.

It had been shown during the 1995/96 census of the Falkland Islands, that it requires little extra effort to census all penguin species during the course of such a census. The only exception to this was the Magellanic Penguin, which because of its widespread, low-density distribution in burrows, made it 
impossible to census with methods employed for surface nesting species (Bingham, 1998b). For this reason the Magellanic Penguin had been excluded from the Falkland Islands census. On that basis it was decided that a census would be conducted of all South American penguins during the 1996/97 breeding season, except for those of the Genus Spheniscus.

During the 1995/96 Falkland Islands census it had been possible to conduct ground counts of incubating pairs at each of the breeding colonies, because most colonies were relatively accessible (Bingham, 1998b). By contrast, many of the South American colonies are remote and inaccessible, and any attempt to conduct ground counts of each and every colony would have been doomed to failure. It was therefore decided from the outset that the census would be conducted by light aircraft, thereby negating the need to get ashore at difficult and remote sites.

The location of all the Falkland Islands breeding sites had been known prior to the commencement of the 1995/96 census (Bingham, 1998b), but this was certainly not the case for South America. Although data did exist for a number of known breeding sites around South America (Frere et al., 1993; Venegas 1984, 1991; Woehler, 1993), it was likely that other sites existed which had not been recorded. This was another reason for favouring an aerial census, since it provided the opportunity to cover large areas of suitable coastline in search of previously unrecorded colonies. This reduced the margin of error that would otherwise arise from new sites being overlooked, however the margin of error for aerial counts was likely to be higher than for ground counts.

In order to quantify the margin of error likely to be expected from aerial counts, a number of aerial censuses were made of Rockhopper colonies in the Falkland Islands for which the number of breeding pairs was also determined by ground counts. These aerial counts differed by a maximum of $14 \%$ from ground counts made of the same colony, suggesting a total margin of error of $\pm 20 \%$ for aerial census data (Bingham 1998a,b).

The 1996/97 aerial census was conducted throughout the known Eudyptes breeding ranges of Chile and Tierra del Fuego (Woehler, 1993). The Atlantic coast of mainland Argentina was excluded from the census, since this coastline has been well studied, and does not hold any breeding sites for species covered by the census, other than a very small Rockhopper colony on Isla Pingüino, near Puerto Deseado (47 $45^{\prime} \mathrm{S} 65^{\circ} 54^{\prime} \mathrm{W}$ ) (Frere et al., 1993, Gandini et al., in press). This colony is regularly monitored as part of an ongoing research programme, and population data from that research was used in favour of duplicating results (Frere et al., 1993).

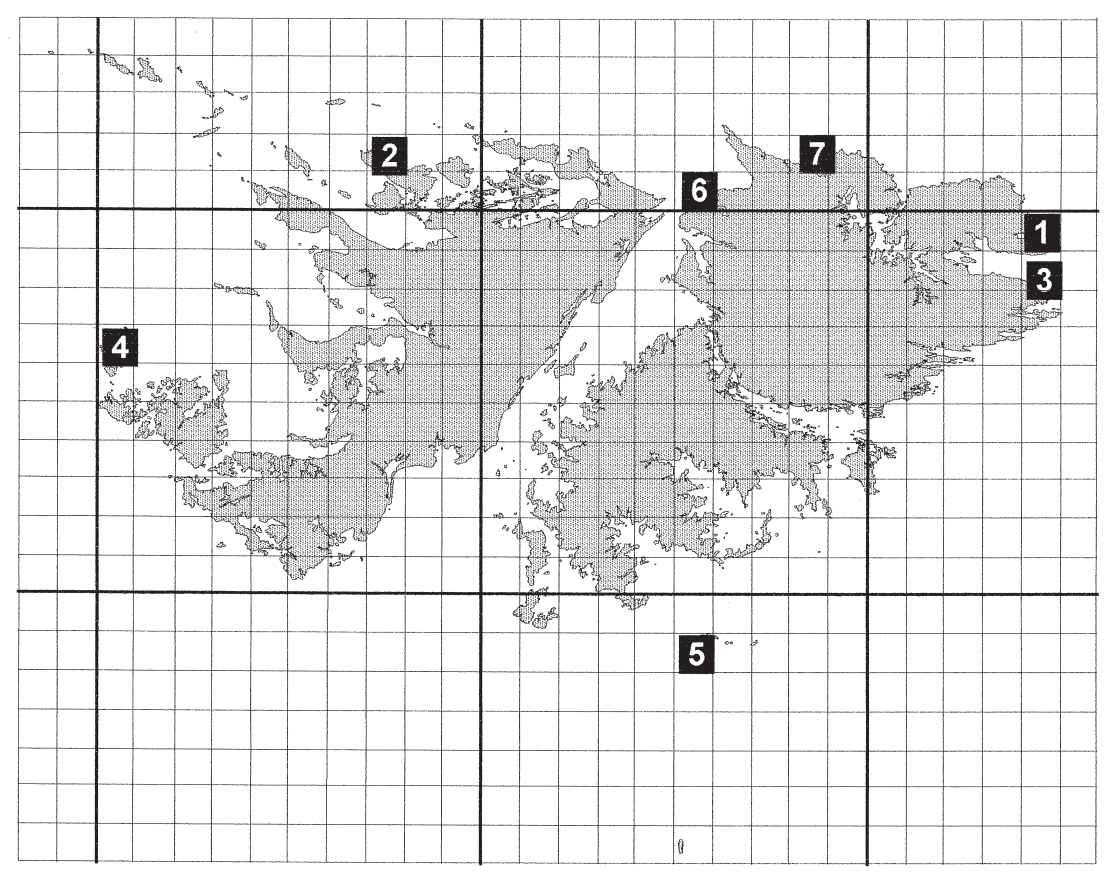

FIG. 1. - Map of Falkland Islands King Penguin breeding sites (numbers refer to Table 1). 
TABLE 1. - Falkland Islands King Penguin counts 1995/96 (site numbers refer to Figure 1).

\begin{tabular}{llc}
\hline & SITE & CHICKS \\
\hline 1 & Volunteer Point & 330 \\
2 & Saunders Island & 3 \\
3 & Kidney Cove & 2 \\
4 & New island & 1 \\
5 & Sea Lion Island & 1 \\
6 & Paloma Beach & 1 \\
7 & Concordia Beach & 339 \\
& TOTAL & \\
\hline
\end{tabular}

\section{RESULTS}

\section{King Penguin}

King Penguins do not make nests, but instead hold eggs and chicks on their feet, making nest counts impossible. For this reason counts are made of chicks and a conversion factor used (Lewis Smith and Tallowin, 1979). The Falkland Islands population census recorded 339 chicks, which equals a total breeding population of approximately 400 breeding pairs (Bingham, 1998b) (Figure 1; Table 1).

King Penguins have not bred in South America since the colony on Islas de los Estados (54'50'S $64^{\circ} 00^{\prime} \mathrm{W}$ ) was wiped out by sealers during the last century (Prosser Goodall, 1979). No King Penguins were recorded anywhere in South America during 1996/97.

\section{Gentoo Penguin}

The Falkland Islands hold around $20 \%$ of the world population of Gentoo Penguin, with a total population of 65,000 breeding pairs at 81 sites being

TABLE 2. - Falkland Islands Gentoo counts 1995/96 (numbers refer to Figure 2).

\begin{tabular}{|c|c|c|c|c|c|}
\hline & SITE & NESTS & . & SITE. & NESTS. \\
\hline 1 & New Island & 5100 & 42 & Great Island & 490 \\
\hline 2 & Steeple Jason Island & 3923 & 43 & Lively Island & 490 \\
\hline 3 & Saunders Island & 3510 & 44 & Beauchene Island & 444 \\
\hline 4 & Albemarle & 2626 & 45 & Town Point & 416 \\
\hline 5 & Bull Point & 2230 & 46 & Gladstone Valley & 410 \\
\hline 6 & Speedwell Island & 2229 & 47 & New Haven & 400 \\
\hline 7 & Grand Jason Island & 2196 & 48 & North Pond & 379 \\
\hline 8 & Carcass Bay & 2039 & 49 & Fox Point & 378 \\
\hline 9 & Shallow Bluff & 1737 & 50 & Little Mountain & 375 \\
\hline 10 & Kidney Cove & 1730 & 51 & Brazo del Mar & 357 \\
\hline 11 & Sea Lion Island & 1484 & 52 & Ten Shilling Bay & 342 \\
\hline 12 & Lucas Hill & 1457 & 53 & Bluff Head & 330 \\
\hline 13 & Grave Cove & 1434 & 54 & The Sandhills & 330 \\
\hline 14 & Port Edgar & 1408 & 55 & Barren Island & 326 \\
\hline 15 & Weddell Island & 1220 & 56 & Cape Orford & 311 \\
\hline 16 & Cape Dolphin & 1148 & 57 & Berthas Beach & 310 \\
\hline 17 & Stevelly Bay & 1071 & 58 & Little Creek & 304 \\
\hline 18 & Whaler Bay & 1000 & 59 & 4th Passage Island & 300 \\
\hline 17 & Volunteer Point & 970 & 60 & Rookery Point & 300 \\
\hline 20 & Stephens Peak & 894 & 61 & Sparrow Cove & 300 \\
\hline 21 & Beaver Island & 892 & 62 & Leopard Bay & 270 \\
\hline 22 & Bleaker Island & 875 & 63 & Rookery Sands & 249 \\
\hline 23 & Seal Bay & 875 & 64 & Port King & 208 \\
\hline 24 & West Head & 855 & 65 & Carcass Island & 180 \\
\hline 25 & Bluff Cove & 850 & 66 & Strike off Point & 176 \\
\hline 26 & Queen Point & 832 & 67 & Fanning Harbour & 160 \\
\hline 27 & Lake Hammond & 830 & 68 & Murdos Cave & 137 \\
\hline 28 & Motley Point & 800 & 69 & Moffit Harbour & 130 \\
\hline 29 & Pebble Island & 754 & 70 & Pleasant Road & 123 \\
\hline 30 & Fox Point & 751 & 71 & Rodeo Point & 120 \\
\hline 31 & Isthmus Cove & 738 & 72 & Cow Bay & 117 \\
\hline 32 & Blue Mountain & 728 & 73 & Salt house & 110 \\
\hline 33 & Big Seal Rook & 716 & 74 & North Beach & 103 \\
\hline 34 & Port North & 705 & 75 & Hoste Inlet & 66 \\
\hline 35 & Concordia Beach & 701 & 76 & Limpet Creek E. & 54 \\
\hline 36 & Hope Point & 654 & 77 & Long Point & 52 \\
\hline 37 & Paloma Beach & 601 & 78 & Colorado Bay & 44 \\
\hline 38 & Bull Roads & 564 & 79 & Shag Harbour & 16 \\
\hline 39 & Keppel Island & 560 & 80 & Ajax Bay & 14 \\
\hline 40 & Bottomless Pond & 534 & 81 & Egg Harbour & 7 \\
\hline 41 & Limpet Creek W. & 531 & & TOTAL & 65,000 \\
\hline
\end{tabular}




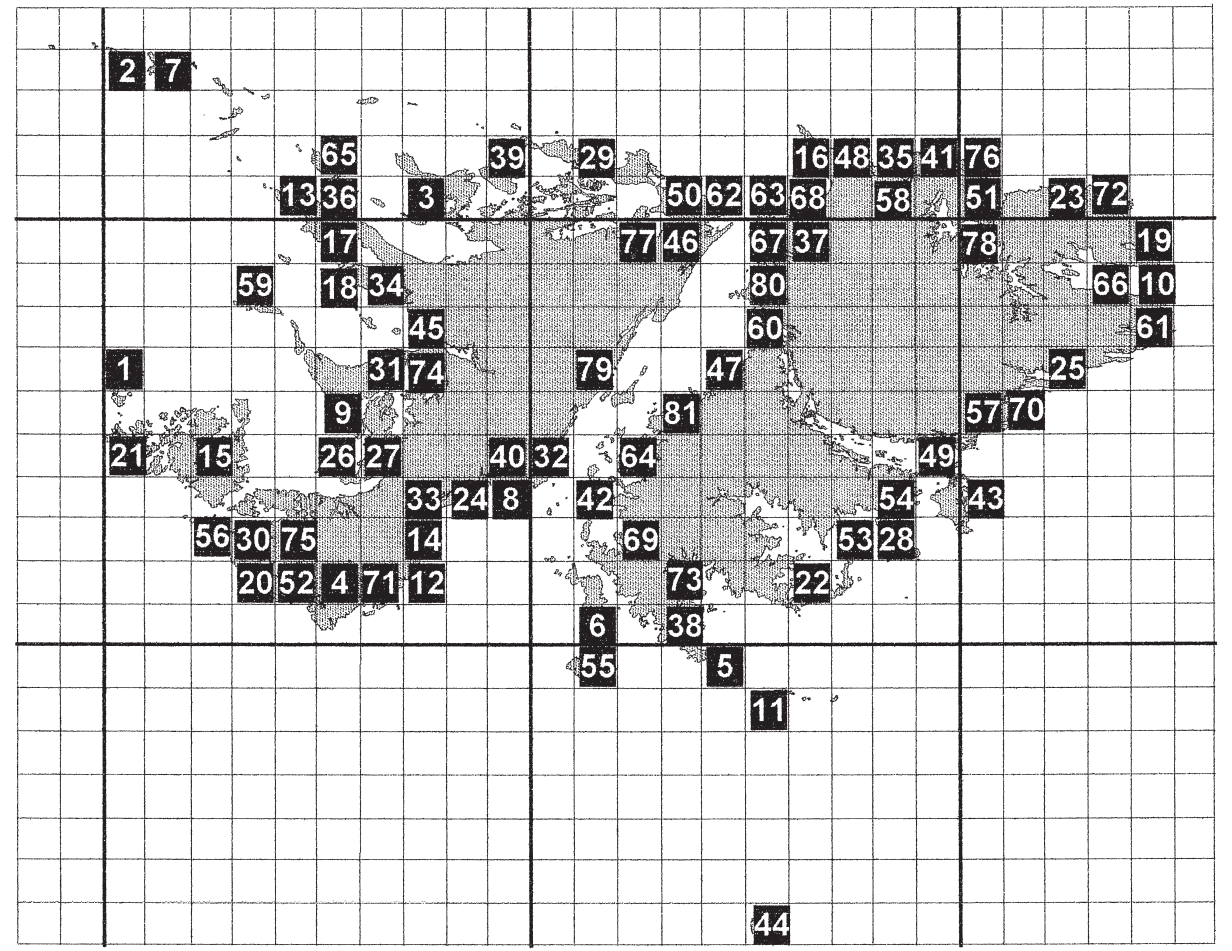

FIG. 2. - Map of Falkland Islands Gentoo breeding sites (numbers refer to Table 2).

recorded during 1995/96 (Bingham, 1998b) (Figure 2 ; Table 2). Somewhat surprisingly, a very small Gentoo breeding colony was discovered on Islas de los Estados (54 $50^{\circ}$ 'S $\left.64^{\circ} 00^{\prime} \mathrm{W}\right)$, containing almost 100 breeding pairs. This was the only breeding colony of Gentoo Penguin recorded in South America.

\section{Southern Rockhopper}

The Falkland Islands and South America are home to two species of the genus Eudyptes; the Southern Rockhopper and the Macaroni (Bingham, 1998a). The Southern Rockhopper is a subspecies

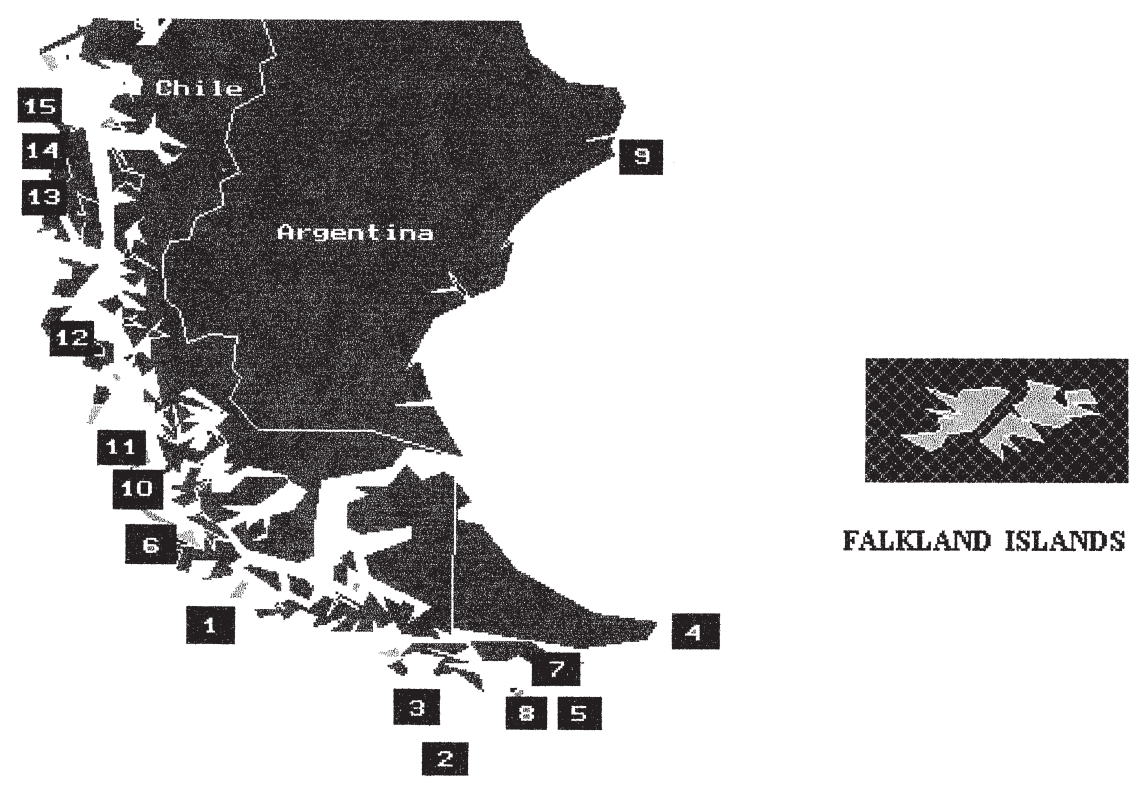

FIG. 3. - Map of South American Rockhopper breeding sites (numbers refer to Table 3). 
TABLE 3. - South American Rockhopper counts 1996/97 (numbers refer to Figure 3).

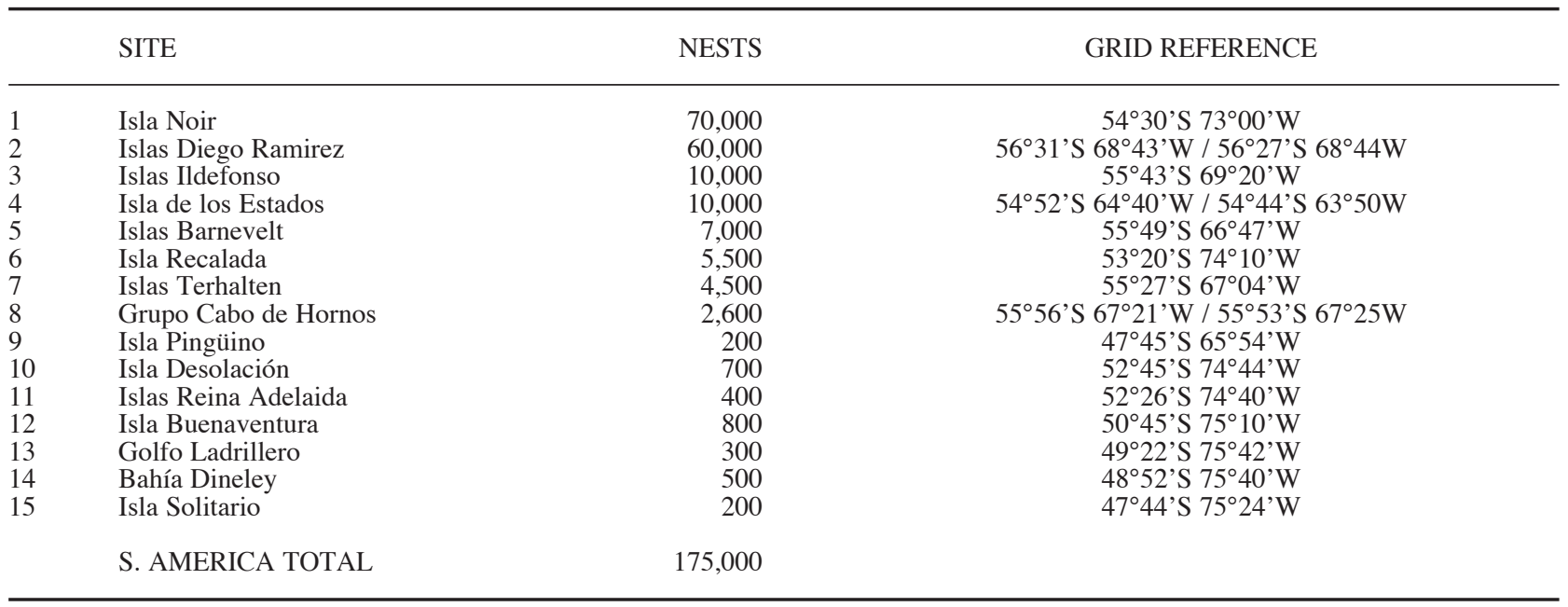

that is restricted to the Falkland Islands and South America (Bingham, 1998b).

The 1996/97 census showed that South America holds a breeding population of about 175,000 pairs of Southern Rockhoppers, at a total of 15 breeding sites (Figure 3; Table 3). Apart from the very small colony on Isla Pingüino (Frere et al., 1993), these breeding sites are restricted to the islands off Tierra del Fuego and Chile. Combined with the Falkland Islands census total of 300,000 pairs at 36 sites (Bingham, 1998b) (Figure 4; Table 4), this gives a world population of 475,000 breeding pairs at 51 sites for the subspecies Eudyptes c. chrysocome. (South Georgia has been known to hold a few breeding pairs, but no more than 10 pairs have been recorded).

\section{Macaroni Penguin}

The Falkland Islands population of Macaroni Penguins is very small, with no individual colonies and only individual pairs found breeding amongst

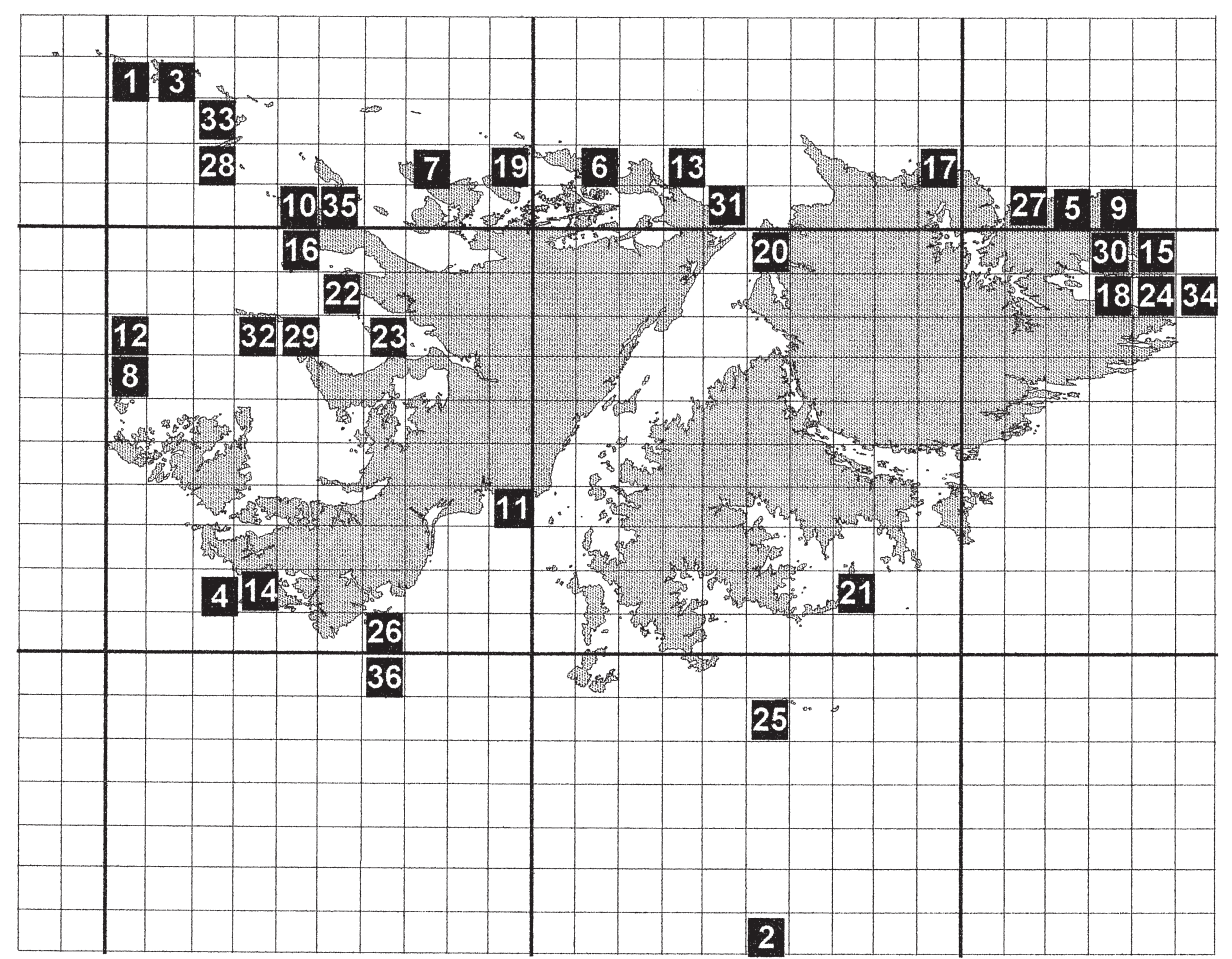

FIG. 4. - Map of Falkland Islands Rockhopper breeding sites (numbers refer to Table 4). 
TABLE 4. - Falkland Islands Rockhopper counts 1995/96 (numbers refer to Figure 4).

\begin{tabular}{|c|c|c|c|c|}
\hline & SITE & NESTS & SITE & ESTS. \\
\hline 1 & Steeple Jason Island & 115000 & 20 Fanning Head & 1071 \\
\hline 2 & Beauchene Island & 74300 & 21 Bleaker Island & 700 \\
\hline 3 & Grand Jason Island & 34000 & 22 Rabbit Island & 600 \\
\hline 4 & Bird Island & 10600 & 23 Hummock Island & 540 \\
\hline 5 & Rabbit Rincon & 8487 & 24 Cochon Island & 515 \\
\hline 6 & Pebble Island & 6702 & 25 Sea Lion Island & 504 \\
\hline 7 & Saunders Island & 5781 & 26 Arch East Island & 411 \\
\hline 8 & New Island & 5500 & 27 Campa Menta & 380 \\
\hline 9 & Macbride Head & 4146 & 28 South Jason Island & 300 \\
\hline & West Point Island & 4042 & 29 1st Passage Island & 267 \\
\hline & Carcass Bay & 3783 & 30 Diamond Cove & 155 \\
\hline & North Island & 3472 & 31 White Rock & 150 \\
\hline 13 & Tamar Point & 2566 & 32 2nd Passage Island & 125 \\
\hline 14 & Stephens Peak & 2504 & 33 Elephant Jason Islan & 100 \\
\hline 15 & Rugged/Eagle Hill & 2460 & 34 Kidney Island & 100 \\
\hline 16 & Deaths Head & 2243 & 35 Grave Cove & 93 \\
\hline 17 & Cape Bougainville & 1943 & 36 Clump Island & 83 \\
\hline 18 & Mount Low & 1910 & \multirow{2}{*}{\multicolumn{2}{|c|}{ Falklands TOTAL 297,000}} \\
\hline 19 & Keppel Island & 1168 & & \\
\hline
\end{tabular}

Rockhoppers colonies. The total Falklands population stands at less than 50 pairs (Bingham,1998a).

The 1996/97 census showed that South America holds a breeding population of about 12,000 pairs of Macaroni, at a total of nine sites (Figure 5; Table 5). These sites are all restricted to the islands off Tierra del Fuego and Chile. Only the islands of Diego Ramirez, Ildefonso and Noir hold more than a thousand breeding pairs.
TABLE 5. - Macaroni Penguin counts 1996/97 (numbers refer to Figure 5).

\begin{tabular}{|c|c|c|c|}
\hline & SITE & NESTS & GRID REFERENCE \\
\hline 1 & Islas Diego Ramirez & 4,500 & $56^{\circ} 31^{\prime} \mathrm{S} 68^{\circ} 43^{\prime} \mathrm{W}$ \\
\hline 2 & Isla Noir & 3,000 & $54^{\circ} 30^{\prime} \mathrm{S} 73^{\circ} 00^{\prime} \mathrm{W}$ \\
\hline 3 & Islas Ildefonso & 2,000 & $55^{\circ} 43^{\prime} \mathrm{S} 69^{\circ} 20^{\prime} \mathrm{W}$ \\
\hline 4 & Isla Recalada & 1,000 & $53^{\circ} 20^{\prime} \mathrm{S} 74^{\circ} 10^{\prime} \mathrm{W}$ \\
\hline 5 & Isla Desolación & 800 & $52^{\circ} 45^{\prime} \mathrm{S} 74^{\circ} 44^{\prime} \mathrm{W}$ \\
\hline 6 & Isla de los Estados & $\sim 50$ & $54^{\circ} 44^{\prime} \mathrm{S} 63^{\circ} 50^{\prime} \mathrm{W}$ \\
\hline 7 & Islas Barnevelt & $\sim 50$ & $55^{\circ} 49^{\prime} \mathrm{S} 66^{\circ} 47^{\prime} \mathrm{W}$ \\
\hline 8 & Islas Terhalten & $\sim 50$ & $55^{\circ} 27^{\prime} \mathrm{S} 67^{\circ} 04^{\prime} \mathrm{W}$ \\
\hline \multirow[t]{3}{*}{9} & Grupo Cabo de Hornos & $\sim 50$ & $55^{\circ} 53^{\prime} \mathrm{S} 67^{\circ} 25^{\prime} \mathrm{W}$ \\
\hline & \multicolumn{3}{|c|}{ South America TOTAL 12,000} \\
\hline & Falkland Islands & $<50$ & \\
\hline
\end{tabular}

\section{Magellanic Penguin}

Of the five species of penguin that regularly breed within the Magellan region, the Magellanic Penguin is the most numerous and widespread (Bingham, 1998a). It only breeds around the coasts of Chile and Argentina, and at the Falkland Islands.

\section{DISCUSSION}

The Falkland Islands population of around 400 breeding pairs of King Penguin has rapidly expand-

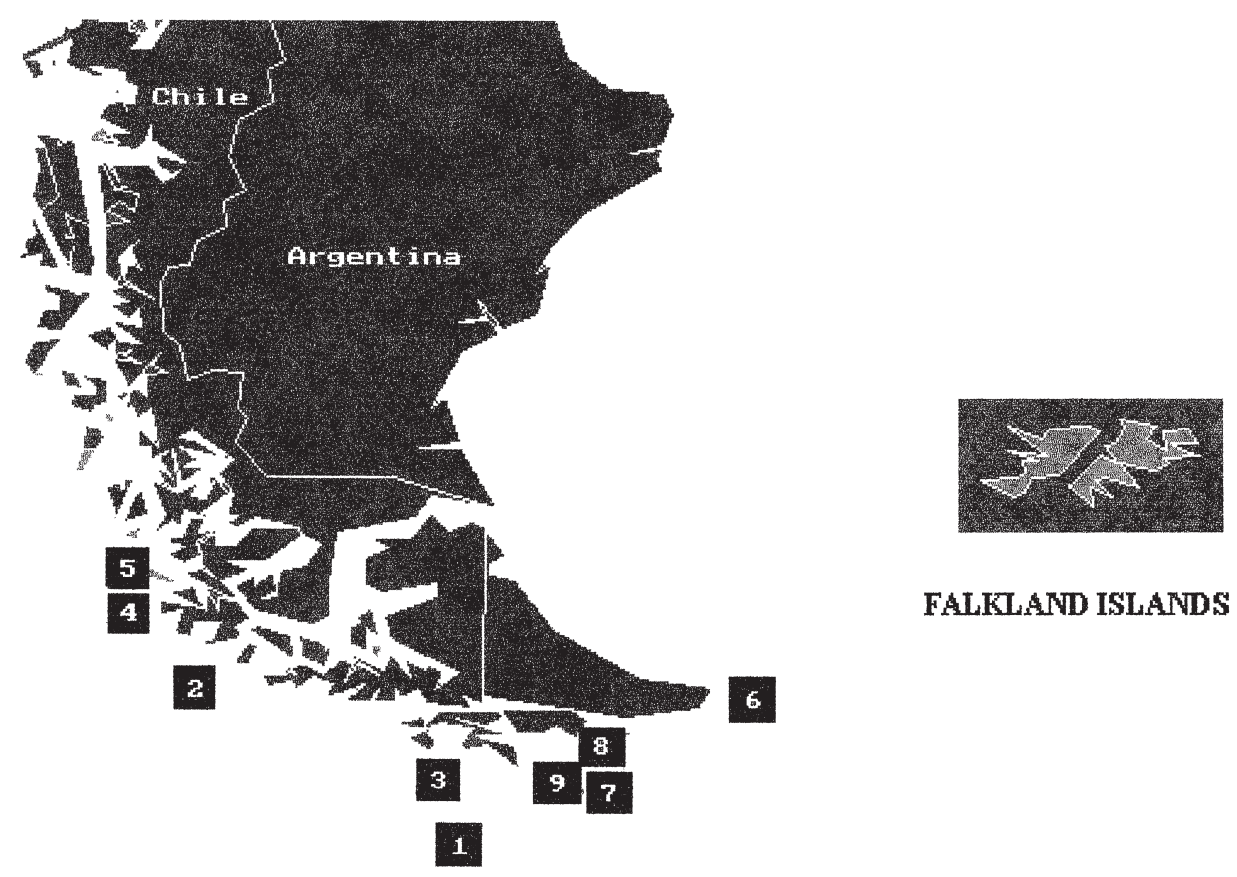

FIG. 5. - Map of Macaroni Penguin breeding sites (numbers refer to Table 5). 
ed from a population of less than 100 pairs recorded during 1980/81 (Bingham, 1995a). With a world population of around 1,500,000 pairs (Woehler, 1993), the Falkland Islands population is of regional rather than global importance.

The Falkland Islands population of around 65,000 breeding pairs of Gentoo Penguin, recorded during the 1995/96 census (Bingham, 1998b), represents about $20 \%$ of the world population of 320,000 pairs (Bingham, 1998a; Woehler, 1993). The 1995/96 Falkland Islands census indicated a population decline of around $45 \%$ since a similar census conducted during 1932/33 (Bennett, 1933).

Annual counts of selected breeding sites around the Falkland Islands suggested that much of this decline had occurred during the late 1980s and early 1990s, with low breeding success also being observed during that period (Bingham, 1994a, d, 1995a). Continued monitoring of these sites since the census indicates that by $1997 / 98$ the Falkland Islands population had risen to around 81,000 breeding pairs (Fig. 6), with high breeding success rates having been recorded from 1993/94 through to 1997/98 (Fig. 7). Gentoo populations are known to fluctuate greatly, and it is plausible that the decline observed previously was merely part of a natural cycle.

The world population of Southern Rockhopper Penguin now stands at around 475,000 breeding pairs, with $63 \%$ of the population in the Falkland Islands and $37 \%$ in South America. Comparison with previous census data (Bennett, 1933) indicates that the Falkland Islands population has crashed to just $10 \%$ of its former size, with much of this decline having occurred during the 1980s and early 1990s (Bingham, 1994c, 1995a, 1998b). Evidence of this dramatic decline can also be seen from the breeding sites themselves. The Falkland Islands breeding

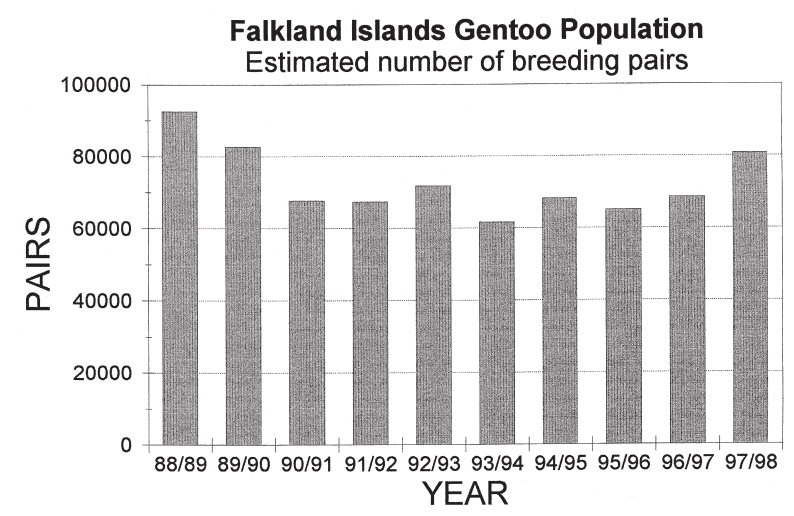

FIG. 6. - Falkland Islands Gentoo Penguin population trends. sites feature old colonies which have destroyed the vegetation by years of occupancy, leaving only lichen covered rocks and stones around the nest-site. The huge breeding colonies that once produced these areas of barren ground, have now been reduced to small clusters of birds huddled in the centre of their stony territories.

The South American population shows no such evidence of decline, with breeding sites featuring a healthy mixture of new, middle-aged and old colonies, indicating a natural cycle of fluctuation and regeneration. Comparison with previous census data (Venegas, 1984, 1991; Woehler, 1993) also indicates that the South American population was stable throughout the 1980s and 1990s, during which the Falkland Islands population crashed (Bingham 1998b). The reason for such differing fortunes is unknown, although it is interesting to note that the waters around Tierra del Fuego and Chile are not heavily fished, whilst those around the Falkland Islands are (Falkland Islands Government, 1989). In the Falkland Islands, even internationally recognised sites, such as Beauchêne Island which is being considered for World Heritage status, have fleets of fishing boats operating just 3 miles from breeding Rockhoppers.

The Macaroni Penguin populations of South America (12,000 pairs) and the Falkland Islands ( $<50$ pairs ) must be looked at in the light of a world population of around 9 million breeding pairs (Bingham, 1998a; Woehler, 1993). These populations are therefore of regional rather than international importance. There were no obvious signs of decline amongst the South American population, and no evidence to suggest that the population has changed greatly over recent years. The Macaroni is the most numerous of all the world's penguins.

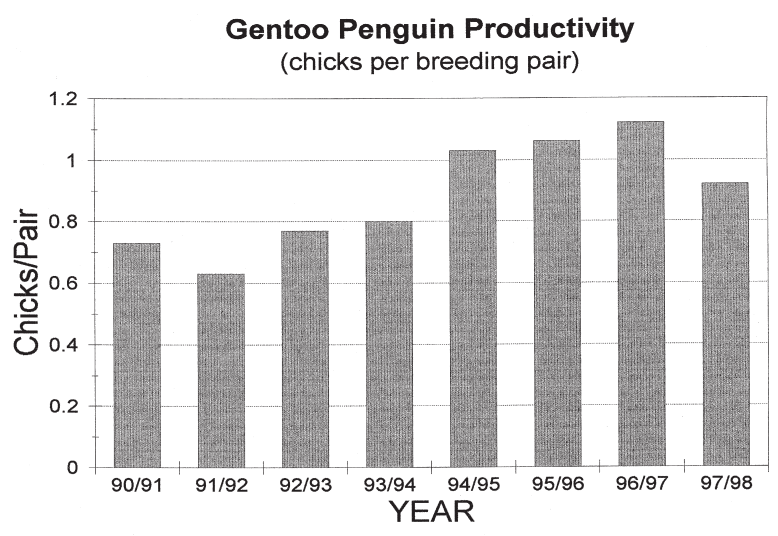

FIG. 7. - Falkland Islands Gentoo Penguin breeding success. 


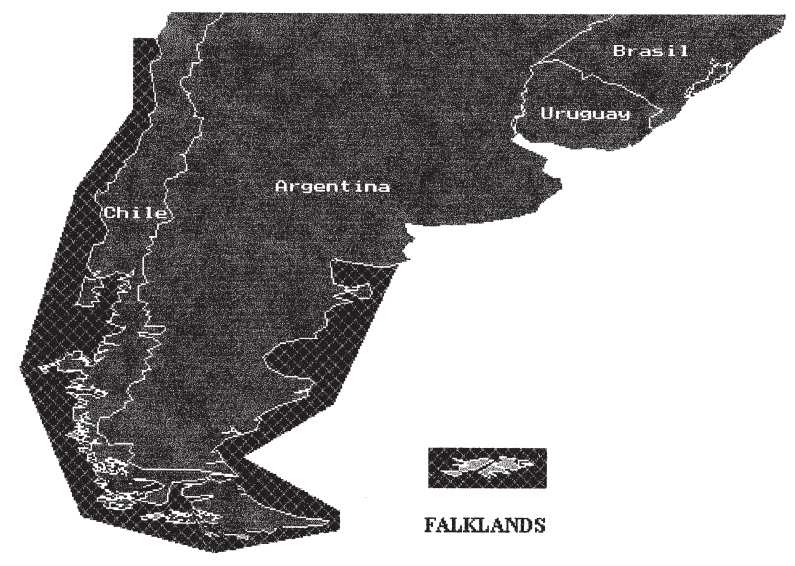

FIG. 8. - Map of Magellanic Penguin breeding range.

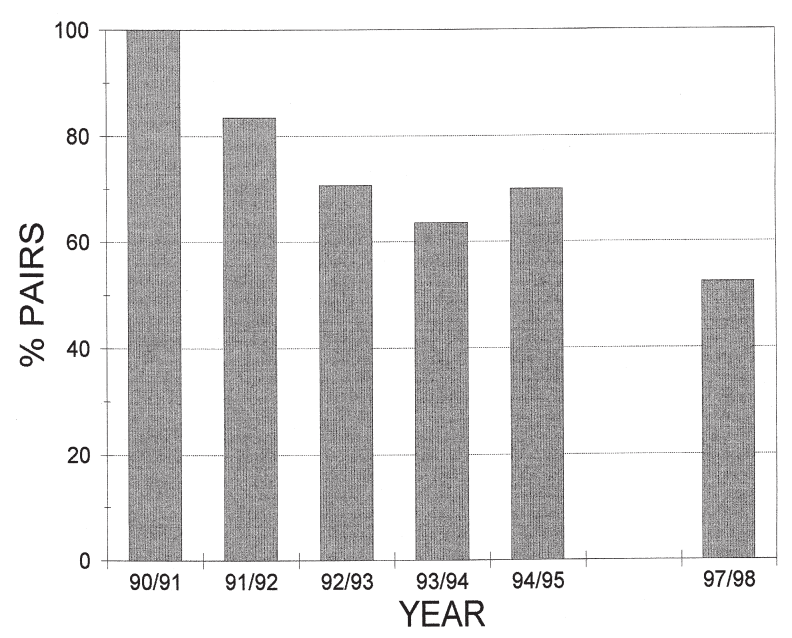

FIG. 9. - Falkland Islands Magellanic Penguin population trends (percentage of 1990/91 population which was $\sim 300,000$ pairs).

Although Magellanic Penguins were not included in the 1995/96 and 1996/97 censuses, that is not to say that no work has been done on this species. The current population along the coast of mainland Argentina is estimated to be 650,000 breeding pairs (Gandini et al., in press). Observations of distribution around Tierra del Fuego and Chile during the 1996/97 census suggest that these regions hold a population at least as large as that of mainland Argentina, giving a South American population of at least 1,300,000 pairs. The Falkland Islands population is well in excess of 100,000 pairs (Bingham, 1998a), giving a minimum world population of around one and a half million breeding pairs (Fig. 8).

Annual monitoring of selected colonies (Bingham, 1994b, 1995a, b) shows that the Magellanic

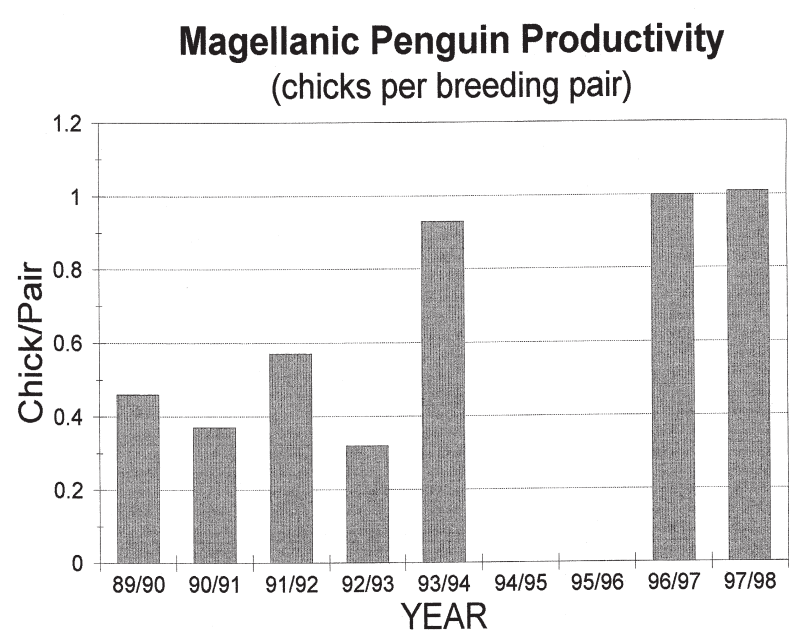

FIG. 10. - Falkland Islands Magellanic Penguin breeding success.

Penguin population of the Falkland Islands has declined to about half its 1980s level (Fig. 9). These declines coincided with observations of low breeding success up until 1993/94 (Fig. 10).

In addition to its Penguin Monitoring Programme in the Falkland Islands, the Environmental Research Unit now conducts similar studies at a number of Chilean breeding sites along the Straits of Magellan. These studies suggest that the Magellanic Penguin decline observed in the Falkland Islands has not been evident in the Magellan region of Chile, despite its close proximity and similar breeding habitat to the Falkland Islands (Bingham, 1998a).

Further evidence of the differing fortunes of the two regions can be seen from the breeding sites themselves. Magellanic Penguin colonies around the Falkland Islands generally feature a very high percentage (on average more than $70 \%$ ) of unoccupied burrows. Similar breeding sites in the Straits of Magellan hold less than half the proportion of unoccupied burrows $(<35 \%)$, suggesting lower levels of adult mortality or higher levels of recruitment (Bingham, 1998a). There is no large-scale fishery in the Straits of Magellan.

\section{ACKNOWLEDGEMENTS}

Thanks go to Falklands Conservation, CONAF, Instituto de la Patagonica, Fundación Otway, Aerovias DAP, Ricardo Fuentes, Dr. John Croxall, and all supporters of the Environmental Research Unit. 


\section{REFERENCES}

Bennett, A.G. - 1933. The Penguin Population of the Falkland Islands in 1932/33. Government Press, Falkland Islands.

Bingham, M. - 1994a. Conservation Report on Gentoo Penguins. Penguin News, 6 (4): 9.

Bingham, M. - 1994b. Conservation Report on Magellanic Penguins. Penguin News, 6 (20): 10.

Bingham, M. - 1994c. Conservation Report on Rockhopper Penguins. Penguin News, 6 (21): 9

Bingham, M. - 1994d. Gentoo Penguin population trends: 1987/88 - 1993/94. The Warrah, 5: 4-5.

Bingham, M. - 1995a. Population status of penguin species in the Falkland Islands. Penguin Conservat., 8 (1): 14-19.

Bingham, M. - 1995b. Seabird Surveys: 1994-95 Report. The Warrah, 5: 5 .

Bingham, M. - 1998a. Penguins of the Falkland Islands and South America. Penguin Conservat., 11 (1): 8-15.

Bingham, M. - 1998b. The distribution, abundance and population trends of Gentoo, Rockhopper and King Penguins at the Falkland Islands. Oryx, 32 (3): 223-32.

Falkland Islands Government. - 1989. Falkland Islands Interim
Conservation and Management Zone Fisheries Report ' $87 / 88$. Falkland Islands Government Report.

Frere, E., M. Gandini, P. Gandini, T. Holik, V. Lichtschein and M.O. Day. - 1993. Variación anual en el número de adultos reproductivos en una nueva colonia de Pingüino Penacho Amarillo en Isla Pingüino (Santa Cruz, Argentina). Hornero, 13: 293-294.

Gandini, P., E. Frere and P.D. Boersma - in press. Status and conservation of Magellanic Penguins in Patagonia, Argentina. Bird Conservat. Internat.

Lewis Smith, R.I. and J.R.B. Tallowin - 1979. The distribution and size of King Penguin rookeries on South Georgia. British Antarct. Survey Bull., 49: 259-276

Prosser Goodall, R.N. - 1979. Tierra del Fuego. Ediciones Shanamaiim, Buenos Aires.

Venegas, C. - 1984. Estado de las poblaciones de Pingüino de Penacho Amarillo y Macaroni en la Isla Noir, Chile. Informe Inst. Patagonia, 33: 1-25.

Venegas, C. - 1991. Estudio de cuantificacion poblacional de pingüinos crestados en Isla Recalada. Informe Inst. Patagonia, 55: $1-23$.

Woehler, E.J. - 1993. The Distribution and Abundance of Antarctic and Subantarctic Penguins. SCAR, Cambridge. 